\title{
Macroalgal Community Structure on the Rocky Shores of Ongdo, Jusamdo, and Woejodo Islands of the Yellow Sea, Korea
}

\author{
Jin Suk Heo, Seo Kyoung Park, Hyun Il Yoo, Ji Na Song, Bo Yeon Kim and Han Gil Choi* \\ Faculty of Biological Science and Institute for Basic Science, Wonkwang University, Iksan, Jeonbuk 570-749, Korea
}

\begin{abstract}
The benthic algal community structures of the seaweed biomass, vertical distribution of dominant seaweeds, and species composition were examined on the rocky shores of Ongdo, Jusamdo, and Woejodo Islands, Korea, in August 2006. A total of 68 seaweeds were identified, comprising 5 green, 11 brown, and 52 red algae from the three study sites. The number of species at Ongdo (32 species) was less than that at Jusamdo (45 species) and Woejodo (44 species). Jusamdo exhibited the maximum seaweed biomass (73.99 $\mathrm{g}$ dry $\mathrm{wt} / \mathrm{m}^{2}$ ), while the minimum value was found at Woejodo (36.90 g dry wt $\left./ \mathrm{m}^{2}\right)$. On the three islands, coarsely branched forms were the most dominant functional group in terms of species number and biomass among benthic algal species. The dominant species were Gelidium amansii, Chondrus ocellatus, and Chrysymenia wrightii at Ongdo, Sargasum thunbergii, Ulva pertusa, and Sargassum fusiformis at Jusamdo, and U. pertusa, Undaria pinnatifida, and Corallina pilulifera at Woejodo. Perennial seaweeds were abundant at Ongdo (G. amansii and C. ocellatus) and Jusamdo (S. thunbergii and S. fusiformis), whereas the sheet form of $U$. pertusa was relatively abundant at Woejodo Island.
\end{abstract}

Key words: Biomass, Community structure, Coverage, Functional form, Seaweed

\section{Introduction}

Marine seaweeds are a major source of primary production, providing habitat and food for associated invertebrates and fishes in marine coastal ecosystems (Terawaki et al., 2001; Bernecker and Wehrtmann, 2009). The pollution and disturbance of macroalgal habitats by human activities reduce species diversity and simplify its community structure (Díez et al., 1999; Kim et al., 2010). Biodiversity, which is high in stable habitats and unpolluted areas, can be used as a biological indicator responding environmental conditions (Piazzi et al., 2002; Arévalo et al., 2007). In addition, seaweed community structures in the intertidal and subtidal zones are influenced by a variety of biotic (grazing and competition) and environmental factors such as substrate characteristics, exposure, and tidal variation (Juul-Pedersen et al., 2008).

Seaweed community structures are generally analyzed by species composition, biomass, coverage, vertical distribution, and functional-form group, which are Parameters that respond to environment conditions (Murray and Littler, 1984; Prathep, 2005; Wells et al., 2007; Choi et al., 2008). The stability of a seaweed community does not always indicate a large seaweed biomass, because opportunistic algae account for substantial biomass in eutrophicated areas (Weston, 1990). In general, water pollution degrades macroalgae, resulting in the reduction of species richness (number), while the biomass of a few ephemeral species increases with high reproductive capability, tolerance to pollution, and simplified community structure (Gorostiaga and Díez, 1996). Thus, seaweed species composition is an ideal parameter for monitoring ecological status (Wells et al., 2007).

Seaweeds can be classified into six functional-form groups based on their morphology, physiology, internal structure, photosynthesis rate, and predation-tolerance strategy (Littler
Open Access http://dx.doi.org/10.5657/FAS.2011.0389

This is an Open Access article distributed under the terms of the Creative Commons Attribution Non-Commercial License (http://creativecommons. org/licenses/by-nc/3.0/) which permits unrestricted non-commercial use, distribution, and reproduction in any medium, provided the original work is properly cited. pISSN: 2234-1749 eISSN: 2234-1757
Received 18 July 2011; Revised 19 September 2011; Accepted 29 September 2011

*Corresponding Author

E-mail: hgchoi@wku.ac.kr 
and Littler, 1984; Padilla and Allen, 2000). Thick-leathery and calcareous functional form seaweeds are dominant in stable environments, whereas green ephemeral algae of both sheet and filamentous forms are generally stress-tolerant species with high reproductive capability in polluted areas (Vásquez and Guerra, 1996; Schramm, 1999; Choi et al., 2008). Thus, the biomass and functional composition of seaweed communities are very important biological parameters that reflect overall environmental conditions (Hay, 1994; Phillips et al., 1997; Ballesteros et al., 2007).

To date, studies of seaweed community structure have been mainly conducted in coastal areas to examine the vertical distribution of dominant seaweeds, variation in seasonal biomass, and the species composition of intertidal rocky shores (Kim et al., 1995; Yoo et al., 2007; Choi and Huh, 2008). However, few studies of the subtidal seaweed assemblages surrounding islands in the Yellow Sea have been performed due to sampling difficulties and the high coasts of SCUBA and boating equipments (Baek et al., 2007; Choi et al., 2008; Wan et al., 2009; Kim et al., 2010). Therefore, the aim of the present study was to examine seaweed community structures using species compositions and functional groups as descriptors to contribute to the knowledge of intertidal and subtidal seaweed vegetation surrounding Ongdo, Jusamdo, and Woejodo Islands.

\section{Materials and Methods}

Seaweed community structures and their abundances were examined at intertidal and subtidal zones of Ongdo $\left(36^{\circ} 38^{\prime} \mathrm{N}\right.$, $\left.126^{\circ} 00^{\prime} \mathrm{E}\right)$, Jusamdo $\left(35^{\circ} 48^{\prime} \mathrm{N}, 126^{\circ} 24^{\prime} \mathrm{E}\right)$, and Woejodo $\left(35^{\circ} 35^{\prime} \mathrm{N}, 126^{\circ} 13^{\prime} \mathrm{E}\right)$ Islands, the Yellow Sea, Korea, in August 2006 (Fig. 1). Subtidal levels were established from the Undaria pinnatifida and Sargassum fusiformis zones as described previously (Kim et al., 2010). For quantitative data collection, five replicated quadrats $(50 \mathrm{~cm} \times 50 \mathrm{~cm})$ were randomly placed within each intertidal zone (high, mid, and low) and subtidal shore $(-1,-5$, and $-10 \mathrm{~m}$ depths from the Undaria pinnatifida zone) during low tide. Seaweeds were collected from the subtidal rocky shores by SCUBA diving. After recording the coverage and frequency, all seaweeds within each quadrat were destructively collected using a scraper following the methods of Saito and Atobe (1970), put into plastic bags, preserved in a $5-10 \%$ formalin:seawater solution, and transported to the laboratory. Qualitative sampling was also conducted to examine the macroalgal flora at the three study sites.

At the laboratory, seaweeds were rinsed with tap water and identified following the classification and nomenclature of Lee and Kang (2002). The seaweeds collected from each quadrat were measured for dry weight, and their biomass was calculated. Using the coverage and frequency data, the relative coverage (RC), relative frequency (RF), and importance value (IV) of each species was calculated. In addition, all

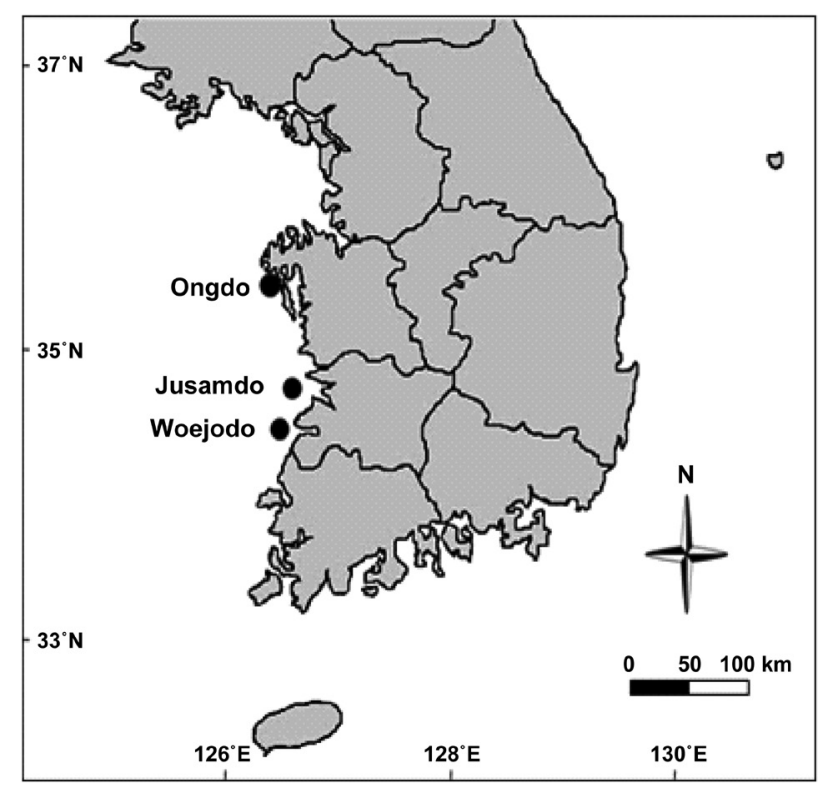

Fig. 1. A map of study sites and the location of Ongdo, Jusamdo and Woejodo Islands, Yellow Sea, Korea.

seaweeds were divided into six functional-form groups based on thallus morphology and internal structure: sheet, filamentous, coarsely branched, thick-leathery, jointed-calcareous, and crustose forms (Littler and Littler, 1984; Steneck and Dethier, 1994; Padilla and Allen, 2000). The biomass of each group was calculated. The dominance index was calculated based on seaweed biomass using the method of McNaughton (1967). Diversity $\left(H^{\prime}\right)$, richness (R), and evenness $\left(J^{\prime}\right)$ indices were assessed with biomass data of each species using the PRIMER statistical package (version 6.0). Similarities among the three study sites based on seaweed biomass $\left(\mathrm{g}\right.$ dry wt $/ \mathrm{m}^{2}$ ) transformed data were calculated using a cluster analysis. The similarity profile test (SIMPROF) was used to examine the difference within each of the groups identified by the cluster analysis. K-dominance curves using seaweed biomass ( $\mathrm{g}$ dry $\mathrm{wt} / \mathrm{m}^{2}$ ) data were also obtained using PRIMER to compare dominance patterns for the three study sites (Lambshead et al., 1983).

\section{Results}

A total of 68 species including 5 green, 11 brown, and 52 red algae were identified at the three islands (Table 1). Howev$\mathrm{er}$, the total number of species present was significantly lower at Ongdo Island than at Jusamdo and Woejodo. In total, 32 species ( 2 green, 4 brown, and 26 red) were found along the Ongdo rocky shore, whereas 45 seaweeds ( 4 green, 9 brown, and 32 red) and 44 species ( 2 green, 6 brown, and 36 red) were identified at Jusamdo and Woejodo, respectively. Red algae were the dominant taxon in term of species richness, ac- 
Heo et al. (2011) Seaweed Community Structure of Yellow Sea Islands

Table 1. Macroalgal lists, biomass ( $\mathrm{g}$ dry wt/ $\mathrm{m}^{2}$ ) and functional (F) forms occurred at Ongdo, Jusamdo and Woejodo, the Yellow Sea, Korea in August 2006

\begin{tabular}{|c|c|c|c|c|}
\hline Species & Ongdo & Jusamdo & Woejodo & F-Form \\
\hline \multicolumn{5}{|l|}{ Chlorophyta } \\
\hline Ulva pertusa & 1.75 & 4.24 & 3.71 & S \\
\hline Ulva sp. & + & + & & S \\
\hline Cladophora albida & & + & & F \\
\hline C. stimpsonii & & & 0.01 & $\mathrm{~F}$ \\
\hline Bryopsis plumosa & & 0.11 & & F \\
\hline \multicolumn{5}{|l|}{ Phaeophyta } \\
\hline Desmarestia ligulata & & 1.41 & & $\mathrm{CB}$ \\
\hline Leathesia difformis & & & + & S \\
\hline Myelophycus simplex & 0.67 & 0.01 & 1.75 & $\mathrm{CB}$ \\
\hline Sphacelaria furcigera & & & + & $\mathrm{F}$ \\
\hline Undaria pinnatifida & 5.53 & 0.01 & 8.59 & $\mathrm{TL}$ \\
\hline Dictyopteris divaricata & & 0.18 & 0.64 & $\mathrm{CB}$ \\
\hline D. undulata & & + & & $\mathrm{CB}$ \\
\hline Sargassum fusiformis & + & 8.15 & & $\mathrm{CB}$ \\
\hline S. fulvellum & & + & & $\mathrm{CB}$ \\
\hline S. thunbergii & 0.03 & 49.14 & 2.78 & $\mathrm{CB}$ \\
\hline Sargassum sp. & & 0.46 & & $\mathrm{CB}$ \\
\hline \multicolumn{5}{|l|}{ Rhodophyta } \\
\hline Bangia atropurpurea & & & + & $\mathrm{F}$ \\
\hline Auduinella codicola & & & + & $\mathrm{CB}$ \\
\hline Gelidium amansii & 27.00 & 0.03 & 2.61 & $\mathrm{CB}$ \\
\hline G. divaricatum & & 0.07 & 1.46 & $\mathrm{CB}$ \\
\hline G. elegans & & & 0.87 & $\mathrm{CB}$ \\
\hline G. pacificum & & & 0.18 & $\mathrm{CB}$ \\
\hline Gelidiella sp. & & + & & $\mathrm{CB}$ \\
\hline Pterocladia capillacea & 0.57 & & + & $\mathrm{CB}$ \\
\hline Lithophyllum sp. & + & + & + & $\mathrm{C}$ \\
\hline Amphiroa dilatata & + & 0.16 & & $\mathrm{JC}$ \\
\hline Bossiella cretacea & 0.61 & & & $\mathrm{JC}$ \\
\hline Corallina officinalis & & + & & $\mathrm{JC}$ \\
\hline C. pilulifera & 0.16 & 4.17 & 7.23 & JC \\
\hline Carpopeltis affinis & 0.32 & 2.55 & 0.04 & $\mathrm{CB}$ \\
\hline Grateloupia divaricata & 0.04 & & 0.00 & $\mathrm{CB}$ \\
\hline G. filicina & & + & & $\mathrm{CB}$ \\
\hline G. prolongata & & 0.13 & 0.00 & $\mathrm{CB}$ \\
\hline G. sparsa & + & & & $\mathrm{CB}$ \\
\hline G. turuturu & 0.46 & + & 0.12 & $\mathrm{TL}$ \\
\hline G. elliptica & 0.06 & 0.02 & + & $\mathrm{TL}$ \\
\hline Prionitis elata & & & 0.02 & $\mathrm{CB}$ \\
\hline P. patens & & + & & $\mathrm{CB}$ \\
\hline P. divaricata & & + & & $\mathrm{CB}$ \\
\hline Gloiopeltis furcata & 0.09 & & & $\mathrm{CB}$ \\
\hline
\end{tabular}


Table 1. Continued

\begin{tabular}{|c|c|c|c|c|}
\hline Species & Ongdo & Jusamdo & Woejodo & F-Form \\
\hline G. tenax & 0.02 & & & $\mathrm{CB}$ \\
\hline Callophyllis palmata & & + & & $\mathrm{S}$ \\
\hline Kallymenia crassiuscula & 6.43 & 0.02 & & $\mathrm{~S}$ \\
\hline Caulacanthus okamurae & 0.40 & 0.22 & 1.38 & $\mathrm{CB}$ \\
\hline Gracilaria textorii & 7.50 & 0.05 & 1.53 & $\mathrm{CB}$ \\
\hline Ahnfeltia plicata & + & + & + & $\mathrm{CB}$ \\
\hline A. paradoxa & 0.99 & 0.12 & 0.15 & $\mathrm{CB}$ \\
\hline Chondrus ocellatus & 7.87 & + & & $\mathrm{CB}$ \\
\hline Chondracanthus tenellus & 0.38 & & + & $\mathrm{CB}$ \\
\hline Chrysymenia wrightii & 3.52 & + & 0.09 & $\mathrm{CB}$ \\
\hline Lomentaria catenata & & + & + & $\mathrm{CB}$ \\
\hline L. hakodatensis & & 0.02 & + & $\mathrm{CB}$ \\
\hline Champia parvula & & 0.42 & 0.07 & $\mathrm{~F}$ \\
\hline Antithamnion nipponicum & & & + & $\mathrm{F}$ \\
\hline Ceramium japonicum & & 0.01 & 0.04 & $\mathrm{~F}$ \\
\hline C. boydenii & & & + & $\mathrm{F}$ \\
\hline C. kondoi & & & + & $\mathrm{F}$ \\
\hline Ceramium sp. & + & & + & $\mathrm{F}$ \\
\hline Acrosorium polyneurum & + & 0.10 & + & $\mathrm{S}$ \\
\hline Marionella schmitziana & & & 0.11 & $\mathrm{~S}$ \\
\hline Polyneura japonica & & + & & $\mathrm{S}$ \\
\hline Chondria crassicaulis & 0.11 & 0.51 & 3.19 & $\mathrm{CB}$ \\
\hline Laurencia intermedia & & 0.03 & & $\mathrm{CB}$ \\
\hline L. venusta & 0.01 & & & $\mathrm{CB}$ \\
\hline Polysiphonia japonica & & & + & $\mathrm{F}$ \\
\hline P. morrowii & & 0.08 & 0.13 & $\mathrm{~F}$ \\
\hline Polysiphonia sp. & & & + & $\mathrm{F}$ \\
\hline Symphyocladia latiuscula & 0.57 & 1.57 & 0.20 & $\mathrm{CB}$ \\
\hline Total biomass & 65.09 & 73.99 & 36.90 & \\
\hline No. of species & 32 & 45 & 44 & \\
\hline
\end{tabular}

S, Sheet form; F, Filamentous form; CB, Coarsely Branched form; TL, Thick Leathery form; JC, Jointed Calcareous form; +, present.

counting for an average of $76.47 \%$ (52 species) of the species at all three study sites, ranging from $71.11 \%$ (32 species) at Jusamdo to $81.82 \%$ (36 species) at Ongdo. A total of 1 green (Ulva pertusa), 3 brown (Myelophycus simplex, Undaria pinnatifida, Sargassum thunbergii), and 14 red algae were common along the rocky shores of all three islands (Table 1).

\section{Biomass}

The seaweed biomass was greatest at Jusamdo (73.99 g dry $\left.\mathrm{wt} / \mathrm{m}^{2}\right)$, followed by Ongdo $\left(65.09 \mathrm{~g}\right.$ dry $\left.\mathrm{wt} / \mathrm{m}^{2}\right)$ and Woejodo (36.90 g dry wt $/ \mathrm{m}^{2}$ ) (Table 2). The biomasses of the macroalgal taxon groups ranged from 1.75-57.11 g dry wt $/ \mathrm{m}^{2}(2.69$ $87.74 \%$ ) at Ongdo to $3.72-19.42 \mathrm{~g}$ dry $w \mathrm{t} / \mathrm{m}^{2}(10.08-52.63 \%)$ at Woejodo. Red and green algae accounted for the highest and lowest biomasses at Ongdo and Woejodo Islands, respec- tively (Fig. 2). At Jusamdo, the seaweed biomasses were as follows: $4.35 \mathrm{~g}$ dry $\mathrm{wt} / \mathrm{m}^{2}$ (5.88\%, green), $10.28 \mathrm{~g}$ dry $\mathrm{wt} / \mathrm{m}^{2}$ $\left(13.89 \%\right.$, red), and $59.36 \mathrm{~g}$ dry $\mathrm{wt} / \mathrm{m}^{2}(80.23 \%$, brown) (Fig. 2). Jusamdo Island was unique in that the brown seaweeds showed the highest biomass.

The vertical distribution of seaweed biomasses showed clearly different patterns at the three study sites (Fig. 3). At Ongdo Island, the macroalgal biomass was distributed from the high intertidal zone to the $-10 \mathrm{~m}$ subtidal zone and ranged from $10.39 \mathrm{~g}$ dry wt $/ \mathrm{m}^{2}$ to $134.00 \mathrm{~g}$ dry $\mathrm{wt} / \mathrm{m}^{2}$ at $-10 \mathrm{~m}$ at these locations, respectively (range: 6 to 10 species). At Jusamdo, seaweeds were present within the high intertidal zone to $-5 \mathrm{~m}$ depth, with biomasses ranging from $10.50 \mathrm{~g}$ dry $\mathrm{wt} / \mathrm{m}^{2}$ at $-5 \mathrm{~m}$ depth to $136.48 \mathrm{~g}$ dry $\mathrm{wt} / \mathrm{m}^{2}$ in the high intertidal zone (species richness, 6-19 species). The distribution of seaweeds was narrow from the mid intertidal zone to the $-5 \mathrm{~m}$ depth zone with 


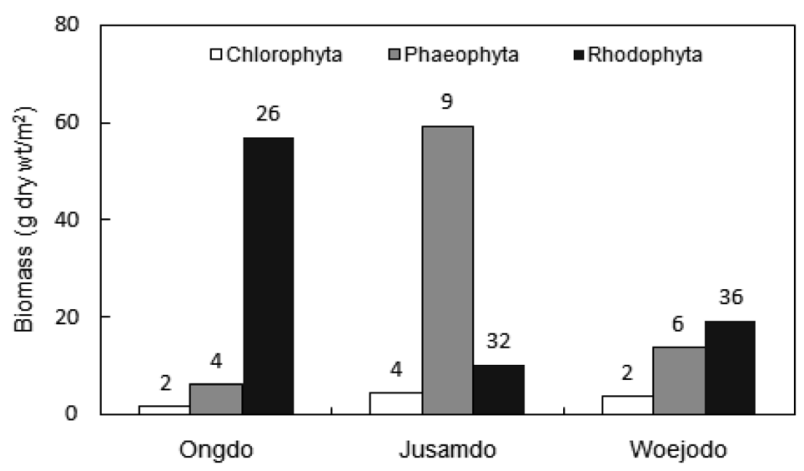

Fig. 2. Seaweed biomass $\left(g \mathrm{dry} w \mathrm{wt} / \mathrm{m}^{2}\right.$ ) and species richness of each taxon group occurred at Ongdo, Jusamdo and Woejodo Islands, the Yellow Sea, Korea.

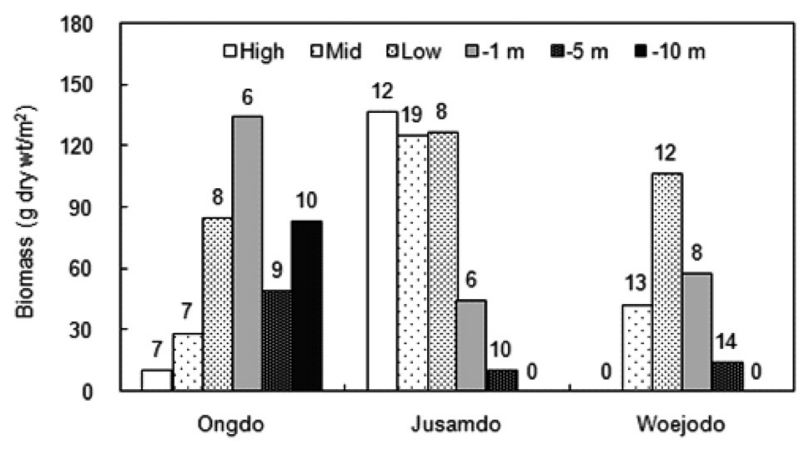

Fig. 3. Vertical variations of seaweed biomass (g dry wt $/ \mathrm{m}^{2}, n=5 \mathrm{rep}$ licates) and species number occurred on each shore levels of Ongdo, Jusamdo and Woejodo Islands, the Yellow Sea, Korea.

Table 2. Average biomass ( $\mathrm{g}$ dry $\mathrm{wt} / \mathrm{m}^{2}$ ), percent coverage (\%) and various community indices for seaweed biomass at Ongdo, Jusamdo and Woejodo Islands, the Yellow Sea, Korea

\begin{tabular}{lccc}
\hline Community indices & Ongdo & Jusamdo & Woejodo \\
\hline Biomass $\left(\mathrm{g}\right.$ dry wt $\left./ \mathrm{m}^{2}\right)$ & 65.09 & 73.99 & 36.90 \\
Coverage (\%) & 15.41 & 12.09 & 11.23 \\
Dominance index (DI) & 0.54 & 0.77 & 0.43 \\
Diversity index (H') & 1.99 & 1.35 & 2.39 \\
Richness index (R) & 7.42 & 10.22 & 11.90 \\
Evenness index (J') & 0.57 & 0.35 & 0.63 \\
\hline
\end{tabular}

seaweed biomass ranging from $14.41 \mathrm{~g}$ dry wt $/ \mathrm{m}^{2}$ to $106.69 \mathrm{~g}$ dry $\mathrm{wt} / \mathrm{m}^{2}$ at the low intertidal shore (from 8 to 14 species). The largest seaweed biomass was found at the $-1 \mathrm{~m}$ depth zone (Ongdo), in the high intertidal zone of Jusamdo, and at the low intertidal zone of Woejodo (Fig. 3). In terms of vertical distribution, there was no clear relationship between species richness and biomass, and the species richness was highest in the $-10 \mathrm{~m}$ subtidal zone off of the Ongdo shore as well as in the mid-intertidal zone (Jusamdo and Woejodo). Macroalgal

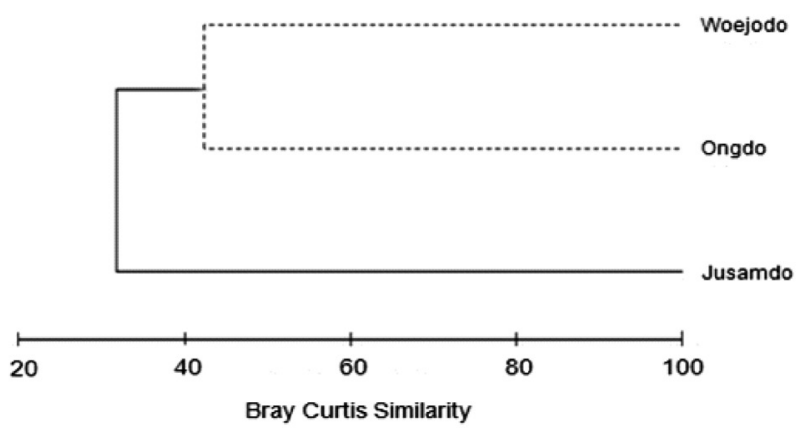

Fig. 4. Results of cluster analysis performed on Bray Curtis Similarity using seaweed biomass $\left(\mathrm{g} \mathrm{dry} \mathrm{wt} / \mathrm{m}^{2}\right.$ ) at the three study sites, Yellow Sea, Korea in August 2006. The dotted lines indicate no significant difference in similarity between the study sites (SIMPROF test).

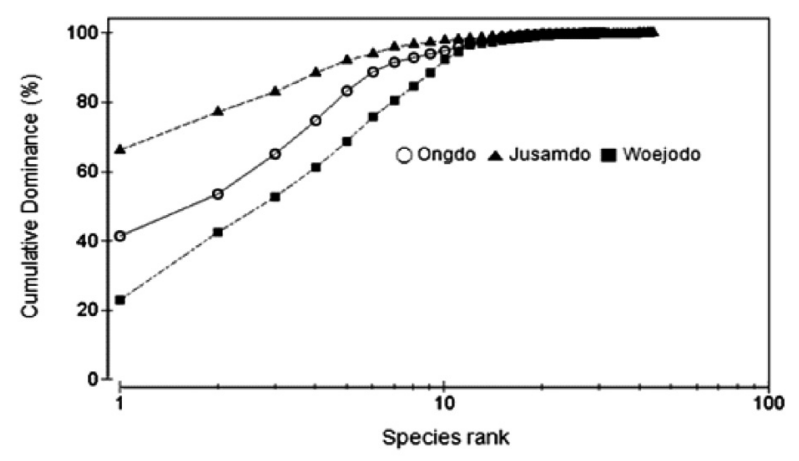

Fig. 5. K-Dominance curves ( $x$-axis logged) for average biomass (g dry $\mathrm{wt} / \mathrm{m}^{2}$ ) of seaweeds at Ongdo, Jusamdo, and Woejodo Islands, the Yellow Sea, Korea.

biomass was greater in the intertidal zone than in the subtidal zone at both Jusamdo and Woejodo, whereas the opposite pattern was observed at Ongdo. The average biomass of intertidal seaweeds ranged from $41.40 \mathrm{~g}$ dry $\mathrm{wt} / \mathrm{m}^{2}$ (Ongdo) to 129.56 g dry $\mathrm{wt} / \mathrm{m}^{2}$ (Jusamdo), while that of the subtidal zone was between $27.67 \mathrm{~g}$ dry wt $/ \mathrm{m}^{2}$ (Jusamdo) and $91.70 \mathrm{~g}$ dry wt $/ \mathrm{m}^{2}$ (Ongdo) calculated from depths of $-1 \mathrm{~m}$ to $-5 \mathrm{~m}$.

The similarity analysis using seaweed biomass data at the three study sites clustered the data into the Jusamdo group and the Ongdo-Woejodo group (Fig. 4). The similarity between these groups was $32.04 \%$, which was significantly different in terms of seaweed biomass (SIMPROF test, $P<0.05$ ). However, the similarity between Ongdo and Woejodo was $42.71 \%$, which was not significantly different.

The K-Dominance curves based on seaweed biomass were slightly different between the three study sites in terms of species evenness (Fig. 5). On the rocky shore of Jusamdo Island, the dominant seaweeds Sargassum thunbergii (49.14 g dry wt/ $\mathrm{m}^{2}$, species rank 1), Sargassum fusiformis $\left(8.15 \mathrm{~g} \mathrm{dry} \mathrm{wt} / \mathrm{m}^{2}\right.$, rank 2), and Ulva pertusa (4.24 g dry wt $/ \mathrm{m}^{2}$, rank 3 ) occupied more than $83.16 \%$ of the total biomass (Fig. 5). At Ongdo, the shape of the curve suggested substantial dominance by three 
species: Gelidium amansii (27.00 g dry wt $/ \mathrm{m}^{2}$, species rank 1), Chondrus ocellatus ( $7.87 \mathrm{~g} \mathrm{dry} \mathrm{wt} / \mathrm{m}^{2}$, rank 2), and Gracilaria textorii (7.50 g dry wt $/ \mathrm{m}^{2}$, rank 3), which made up $65.09 \%$ of the total algal biomass in August 2006. At Woejodo, Undaria pinnatifida ( $8.59 \mathrm{~g}$ dry wt $/ \mathrm{m}^{2}$, species rank 1$)$, Corallina pilulifera (7.23 g dry wt $/ \mathrm{m}^{2}$, rank 2), and Ulva pertusa (3.71 g dry $w t / \mathrm{m}^{2}$, rank 3) accounted for $52.93 \%$ of the total algal biomass. The dominance indices (DI) based on biomass data were 0.43 for Woejodo, 0.54 for Ongdo, and 0.77 for Jusamdo. At Jusamdo, in terms of biomass, the first and second most dominant species were Sargassum thunbergii and S. fusiformis, respectively, occupying approximately $77 \%$ of the total biomass. Evenness indices were negatively correlated with DI and ranged from 0.35 at Jusamdo to 0.63 at Woejodo. The diversity $\left(\mathrm{H}^{\prime}\right)$ and richness $(\mathrm{R})$ indices, which are calculated based on species number and evenness of seaweed biomass, respectively, were greatest at Woejodo (Table 2). The diversity index ranged from 1.35 to 2.39 while the richness index was 7.42 at Ongdo and 11.90 along the Woejodo shore (Table 2).

\section{Coverage}

The seaweed coverage was greatest at Ongdo (16.61\%), followed by Jusamdo (14.51\%) and Woejodo (13.48\%). The average seaweed coverage along the Ongdo rocky shore was $16.61 \%$ from the high intertidal zone to the $-5 \mathrm{~m}$ zone (we excluded the $-10 \mathrm{~m}$ coverage to enable comparisons with the other islands), and varied vertically from $3.60 \%$ to $30.86 \%$. The total seaweed coverage was $14.51 \%$ (from 2.70 at $-5 \mathrm{~m}$ depth to $23.55 \%$ at the mid intertidal zone) at Jusamdo and $13.48 \%$ on the Woejodo rocky shore (from $0.00 \%$ in the high intertidal zone to $25.99 \%$ in the low intertidal zone). The seaweed coverage at Ongdo was greater in the subtidal zone $(22.01 \%)$ than in the intertidal zone $(13.00 \%)$. Conversely, the algal coverage at both Jusamdo (21.73\% in the intertidal zone, $3.68 \%$ in the subtidal zone) and Woejodo $(14.06 \%, 12.60 \%)$ were highest in the intertidal zones.

Abundant species (IV > 10) were Gelidium amansii, Chondrus ocellatus, and Chrysymenia wrightii at Ongdo Island, and Sargassum thunbergii, Ulva pertusa, and S. fusiformis at Jusamdo. Ulva pertusa, Gracilaria textorii, and Corallina pilulifera dominated the rocky shore of Woejodo Island (Table 3), while Gelidium amansii was dominant at the Ongdo and Woejodo shores. Sargassum thunbergii, U. pertusa, and $C$. pilulifera were abundant along both the Jusamdo and Woejodo shores.

\section{Vertical distribution}

The vertical distributions of the dominant seaweed species based on IV are provided in Table 4. The dominant seaweeds $(I V>20)$ of each shore level at Ongdo Island were Caulacanthus okamurae, Myelophycus simplex, Gelidium amansii, Ahnfeltiopsis paradoxa, Chondrus ocellatus, and Undaria pinnatifida from the upper to lower intertidal zones, and $G$. amansii, Chrysymenia wrightii, Gracilaria textorii, and Kallymenia crassiuscula in the subtidal zone. At the Jusamdo shore, Sargassum thunbergii was dominant from the high to $-1 \mathrm{~m}$ subtidal zones and S. fusiformis was abundant near the subtidal zone. No seaweed species were recorded in the $-10 \mathrm{~m}$ depth regions of the Jusamdo and Woejodo rocky shores. At Woejodo, the dominant species (IV $>20$ ) were $M$. simplex, $C$. okamurae, U. pertusa, Corallina pilulifera, Undaria pinnatifida, G. amansii, and G. textorii from the mid intertidal zone to the $-5 \mathrm{~m}$ subtidal zone (Table 4).

\section{Functional-form groups}

The same six functional-form groups (i.e., sheet, filamentous, coarsely branched, thick-leathery, jointed-calcareous, and crustose forms) were found at all three study sites. The coarsely-branched form was the most dominant group in terms of species number and biomass at all three study sites. The percentage of coarsely-branched form seaweeds ranged from $52.27-60.00 \%$ in species number and $45.77-87.37 \%$ of the total biomass (Fig. 6). On the rocky shores of Ongdo and Judsamdo Islands, the sheet form was the sub-dominant

Table 3. Average coverage (C), frequency $(F)$, relative coverage $(R C)$, relative frequency (RF), and importance value (IV) of seaweeds occurred on the rocky shores of Ongdo, Jusamdo and Woejodo Islands, the Yellow Sea, Korea

\begin{tabular}{lrrrrr}
\hline Site/Species & C & F & RC(\%) & RF(\%) & IV* \\
\hline Ongdo & & & & & \\
$\quad$ Gelidium amansii & 5.53 & 24.00 & 35.85 & 26.20 & 31.02 \\
Chondrus ocellatus & 3.36 & 13.47 & 21.78 & 14.70 & 18.24 \\
Chrysymenia wrightii & 1.39 & 13.87 & 9.00 & 15.14 & 12.07 \\
Gracilaria textorii & 1.19 & 8.40 & 7.75 & 9.17 & 8.46 \\
Undaria pinnatifida & 1.00 & 4.00 & 6.49 & 4.37 & 5.43 \\
Jusamdo & & & & & \\
Sargassum thunbergii & 7.08 & 24.93 & 58.53 & 37.40 & 47.97 \\
Ulva pertusa & 1.53 & 9.60 & 12.67 & 14.40 & 13.53 \\
Sargassum fusiformis & 1.33 & 9.33 & 11.01 & 14.00 & 12.51 \\
Carpopeltis affinis & 0.47 & 4.27 & 3.88 & 6.40 & 5.14 \\
Corallina pilulifera & 0.33 & 4.93 & 2.74 & 7.40 & 5.07 \\
Woejodo & & & & & \\
Ulva pertusa & 1.73 & 13.33 & 15.36 & 18.15 & 16.75 \\
Undaria pinnatifida & 1.67 & 9.33 & 14.86 & 12.70 & 13.78 \\
Corallina pilulifera & 1.05 & 7.87 & 9.35 & 10.71 & 10.03 \\
Gelidium amansii & 1.20 & 6.53 & 10.68 & 8.89 & 9.79 \\
Gracilaria textorii & 0.83 & 6.13 & 7.35 & 8.35 & 7.85 \\
Sargassum thunbergii & 0.89 & 4.40 & 7.90 & 5.99 & 6.95 \\
Myelophycus simplex & 0.83 & 2.93 & 7.40 & 3.99 & 5.70 \\
Caulacanthus okamurae & 0.56 & 3.73 & 5.01 & 5.08 & 5.05 \\
*IV > 5. & & & & &
\end{tabular}


group, accounting for $12.57 \%$ and $5.90 \%$ of the total biomass, respectively. However, at Woejodo, the thick-leathery form (second group, 23.61\%) and jointed-calcareous form (third group, 19.57\%) had very similar biomasses (Fig. 6). As shown in Table 3, Gelidium amansii, Chondrus ocellatus, Chrysymenia wrightii, and Gracilaria textorii were all in the coarselybranched form at Ongdo. Also, the functional form seaweeds, Sargassum thunbergii, S. fusiformis, and Carpopeltis affinis

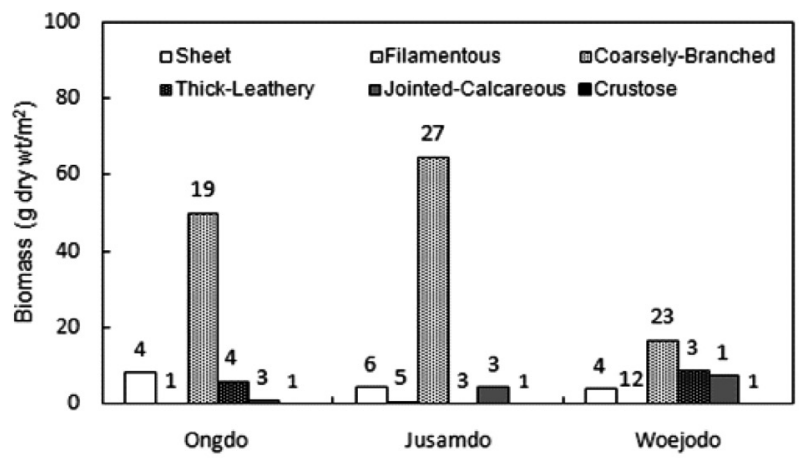

Fig. 6. Average biomass (g dry $w t / \mathrm{m}^{2}$ ) of five functional-form seaweeds on the rocky shore of Ongdo, Jusamdo, and Woejodo Islands, the Yellow Sea, Korea. The number presented species number of each functional form group. were dominant on the Jusamdo rocky shore. However, at Woejodo, the abundant seaweeds (IV > 10) were U. pertusa (sheet), Undaria pinnatifida (thick-leathery), and Corallina pilulifera (jointed-calcareous).

\section{Discussion}

Seaweed species richness is a basic tool showing the conditions of coastal marine ecosystems because it responses sensitively to environmental changes of seaweed habitats (Wells et al., 2007). During summer, seaweed species richness has been reported to vary from 14 species at Oshikto (Park and Kim, 1990) to 16 species at 10 Islands (from Deokjegdo to Seungbongdo Islands) of the Gyonggiman islets (Lee et al., 1997) and 70 species at Sapsido (Yoon and Boo, 1991) in the Yellow Sea, Korea. In the present study, 32, 45, and 44 species were identified at Ongdo, Jusamdo, and Woejodo Islands, respectively, during the summer. These data suggest that the environmental conditions at the three study sites are better than many other island areas in terms of algal species richness.

Seaweed biomass determines the amount of primary production in marine ecosystems because macroalgae are used as food sources of many marine animals (Terawaki et al., 2001; Eklöf et al., 2005). Thus, seaweed biomass is a common indi-

Table 4. Vertical distribution of dominant seaweeds based on importance value (IV > 10) at the three study sites of Yellow Sea, Korea

\begin{tabular}{|c|c|c|c|c|}
\hline \multicolumn{2}{|c|}{ Levels } & Ongdo & Jusamdo & Woejodo \\
\hline \multirow{11}{*}{$\begin{array}{c}\text { Intertidal } \\
\text { Zone }\end{array}$} & High & Caulacanthus okamurae (34.10) & Sargassum thunbergii (68.87) & \\
\hline & & Myelophycus simplex (32.29) & & \\
\hline & & Chondrus ocellatus (13.89) & & \\
\hline & & Gloiopeltis furcata (10.52) & & \\
\hline & Mid & Gelidium amansii (52.07) & Sargassum thunbergii (42.59) & Myelophycus simplex (24.26) \\
\hline & & Ahnfeltiopsis paradoxa (20.73) & Ulva pertusa (29.13) & Caulacanthus okamurae (21.19) \\
\hline & & Pterocladia capillacea (14.21) & & Gelidium divaricatum (17.79) \\
\hline & Low & Chondrus ocellatus (49.20) & Sargassum thunbergii (42.21) & Ulva pertusa (32.94) \\
\hline & & Undaria pinnatifida (21.52) & Sargassum fusiformis (25.76) & Corallina pilulifera (22.36) \\
\hline & & & & Sargassum thunbergii (12.96) \\
\hline & & & & Chondria crassicaulis (12.94) \\
\hline \multirow{10}{*}{$\begin{array}{l}\text { Subtidal } \\
\text { Zone }\end{array}$} & $-1 \mathrm{~m}$ & Gelidium amansii (58.24) & Sargassum thunbergii (46.42) & Undaria pinnatifida (42.92) \\
\hline & & Chrysymenia wrightii (27.17) & Sargassum fusiformis (42.94) & Gelidium amansii (22.01) \\
\hline & & Chondrus ocellatus (11.50) & & Gracilaria textorii (10.76) \\
\hline & & & & Ulva pertusa (10.32) \\
\hline & $-5 \mathrm{~m}$ & Gelidium amansii (29.58) & Desmarestia ligulata (49.54) & Gracilaria textorii (36.10) \\
\hline & & Chrysymenia wrightii (23.82) & Gracilaria textorii (21.76) & Gelidium amansii (15.31) \\
\hline & & Gracilaria textorii (22.46) & Ulva pertusa (10.88) & Undaria pinnatifida (10.71) \\
\hline & & Chondracanthus tenellus (10.08) & & Gelidium elegans (10.55) \\
\hline & $-10 m$ & Gracilaria textorii (43.61) & & \\
\hline & & Kallymenia crassiuscula (28.61) & & \\
\hline
\end{tabular}


cator of the health of marine ecosystems. In the island areas of the Yellow Sea, the average seaweed biomass of the intertidal zone is $89.25 \mathrm{~g}$ dry $\mathrm{wt} / \mathrm{m}^{2}$ and varies from $23.78 \mathrm{~g}$ dry $\mathrm{wt} / \mathrm{m}^{2}$ at Oshikto Island (Park and Kim, 1990) to $176.68 \mathrm{~g}$ dry wt/ $\mathrm{m}^{2}$ at Nachido Island in the summer. At our study sites, the macroalgal biomasses of intertidal rocky shores ranged from $41.40 \mathrm{~g}$ dry wt $/ \mathrm{m}^{2}$ (Ongdo) and $49.83 \mathrm{~g}$ dry $\mathrm{wt} / \mathrm{m}^{2}$ (Woejodo) to $129.56 \mathrm{~g}$ dry wt $/ \mathrm{m}^{2}$ (Jusamdo) in August 2006. Thus, the conditions along the Woejodo and Ongdo shores appeared relatively poor, whereas Jusamdo was in better condition.

The dominant seaweed taxon and seaweed biomass are always tightly correlated (Littler and Littler 1980). Brown algae dominate the island areas of the Yellow Sea, with Sargassum thunbergii being abundant along the shores of Nachido, Wonsando, Kodoedo, Odo, Hodo, and Changgodo Islands (Kim et al., 1995). Red algae were the second most abundant, with Neorhodomela aculeata at Bagryoungdo (Baek et al., 2007) and Corallina pilulifera at Gyounggiman islets (Lee et al., 1997). Green seaweeds tend to only dominate the rocky shores of a few islands. For example, green seaweeds accounted for $38.1 \%$ of the total biomass at Oshikto Island (Park and Kim, 1990). In the present study, red algae (Gelidium amansii, Chondrus ocellatus, and Chrysymenia wrightii) accounted for $58.96 \%$ of the total biomass at Ongdo, while S. thunbergii (brown algae) made up $66.40 \%$ of the total biomass at Jusamdo. On the Woejodo shore, $64.12 \%$ of the total seaweed biomass was composed of Ulva pertusa (green), Undaria pinnatifida (brown), and C. pilulifera, G. amansii, and Gracilaria textorii (red). Generally, brown algae exhibit larger biomasses than red seaweeds due to their larger size, whereas red algae are mostly small or filamentous in form (Johnston, 1969). These taxon differences may explain why the seaweed biomass was greatest at Jusamdo Island, which is dominated by $S$. thunbergii, compared to Woejodo and Ongdo, which are dominated by green and red seaweeds, respectively.

Functional form composition in seaweed community is another important indicator of environmental conditions (Choi et al., 2008). During the summer, coarsely-branched seaweeds are the major group in terms of species number, making up $33.33 \%$ to $78.95 \%$ of the seaweed forms (from Shimwon to Nachido) in the island areas of the Yellow Sea (Hwang et al., 1996; Lee et al., 2007; Yoo et al., 2007). Sheet and filamentous groups exhibit relatively high proportions, ranging from $5.26 \%$ (at Nachido) to $45.45 \%$ (at Hyanghado, Maseom) due to the high water turbidity during the summer (Hwang et al., 1996; Lee et al., 2007; Yoo et al., 2007). Generally, sheet-like and filamentous seaweeds, such as Ulva sp. and Cladophora sp., are dominant in unstable or polluted habitats, whereas late successional, thick-leathery and calcareous seaweeds thrive in stable environmental conditions (Littler and Littler, 1984; Choi et al., 2008; Kim et al., 2010). In addition, coarselybranched seaweeds typically occur in moderate environments (Littler and Littler, 1984). In the present study, we observed that the coarsely-branched form was qualitatively most domi- nant, accounting for 52.27\% (at Woejodo), 59.38\% (at Ongdo), and $60.00 \%$ (at Jusamdo) of all species. Conversely, the sheet-like and filamentous forms made up 15.63\%, 24.44\%, and $36.36 \%$ of all species at Ongdo, Jusamdo, and Woejodo, respectively. The dominant species (Ulva pertusa) of the sheet form was most abundant from mid intertidal zone to $-5 \mathrm{~m}$ depth at Jusamdo and Woejodo, while the desiccation-tolerant species Corallina pilulifera, which is of the jointed-calcareous form, was also abundant in summer at Jusamdo and Woejodo (Choi et al., 2008).

In conclusion, a total of 68 species, including 5 green, 11 brown, and 52 red algae, were identified at three study sites in August 2006. Seaweed biomass was highest at Jusamdo (74.01 g dry wt $/ \mathrm{m}^{2}$ ) and lowest at Woejodo (36.92 g dry wt/ $\mathrm{m}^{2}$ ). The dominant seaweed species included Gelidium amansii, Chondrus ocellatus, and Chrysymenia wrightii at Ongdo, Sargassum thumbergii, Ulva pertusa, and Sargassum fusiformis at Jusamdo, and U. pertusa, Undaria pinnatifida, and Corallina piluifera at Woejodo. Abundant perennial seaweeds (G. amansii and C. ocellatus at Ongdo, S. thunbergii and $S$. fusiformis at Jusamdo) were present in stable environments, whereas sheet algae such as $U$. pertusa thrived in disturbed habitats, such as that at Woejodo Island. On the basis of biomass, IV, and functional form composition of seaweed communities, we conclude that the Jusamdo shore is in the best condition, whereas Woejodo is in the poorest condition in terms of seaweed habitats among the three islands.

\section{Acknowledgments}

We thank the members of the Marine Biological Laboratory, Wonkwang University, for providing help with field and laboratory work. This work was supported by the National Research Foundation of Korea (NRF) grant (NRF-20110012519) to Han Gil Choi.

\section{References}

Arévalo R, Pinedo S and Ballesteros E. 2007. Changes in the composition and structure of Mediterranean rocky-shore communities following a gradient of nutrient enrichment: descriptive study and test of proposed methods to assess water quality regarding macroalgae. Mar Pollut Bull 55, 104-113.

Baek JM, Hwang MS, Lee JW, Lee WJ and Kim JI. 2007. The macroalgal community of Bagryoungdo Island in Korea. Algae 22, 117-123.

Ballesteros E, Torras X, Pinedo S, García M, Mangialajo L and de Torres M. 2007. A new methodology based on littoral community cartography dominated by macroalgae for the implementation of the European Water Framework Directive. Mar Pollut Bull 55, 172-180.

Bernecker A and Wehrtmann IS. 2009. New records of benthic marine 
algae and cyanobacteria for Costa Rica, and a comparison with other Central American countries. Helgol Mar Res 63, 219-229.

Choi CG and Huh SH. 2008. Composition of marine algal community at the intertidal zone in Gwangyang Bay, South Sea, Korea. J Korean Fish Soc 41, 201-207.

Choi HG, Lee KH, Wan XQ, Yoo HI, Park HH, Kim JH and Chung IK. 2008. Temporal variations in seaweed biomass in Korean coasts: Woejodo and Jusamdo, Jeonbuk. Algae 23, 335-342.

Díez I, Secilla A, Santolaria A and Gorostiaga JM. 1999. Phytobenthic intertidal community structure along an environmental pollution gradient. Mar Pollut Bull 38, 463-472.

Eklöf JS, de la Torre Castro M, Adelsköld L, Jiddawi NS and Kautsky N. 2005. Differences in macrofaunal and seagrass assemblages in seagrass beds with and without seaweed farms. Estuar Coast Shelf Sci 63, 385-396.

Gorostiaga JM and Díez I. 1996. Changes in the sublittoral benthic marine marcroalgae in the polluted area of Abra de Bilbao and proximal coast (Northern Spain). Mar Ecol Prog Ser 130, 157-167.

Hay ME. 1994. Species as 'noise' in community ecology: do seaweeds block our view of the kelp forest? Trends Ecol Evol 9, 414-416.

Hwang EK, Park CS, Sohn CH and Koh NP. 1996. Analysis of functional form groups in macroalgal community of Yonggwang vicinity, western coast of Korea. J Korean Fish Soc 29, 97-106.

Johnston CS. 1969. The ecological distribution and primary production of macrophytic marine algae in the Eastern Canaries. Int Rev Gesamten Hydrobiol 54, 473-490.

Juul-Pedersen T, Michel C and Gosselin M. 2008. Influence of the Mackenzie River plume on the sinking export of particulate material on the shelf. J Mar Syst 74, 810-824.

Kim BY, Kim WS and Choi HG. 2010. Seasonal variability of seaweed biomass along the vertical shore gradients of Nachido and Odo islands, the Yellow Sea, Korea. Fish Aquat Sci 13, 324-331.

Kim YH, Yoon HJ and Yoo JS. 1995. Species composition and biomass of marine algal community on the mid-western coast of Korea. J Plant Biol 38, 389-398.

Lambshead PJD, Platt HM and Shaw KM. 1983. The detection of differences among assemblages of marine benthic species based on an assessment of dominance and diversity. J Nat Hist 17, 859-874.

Lee KH, Yoo HI and Choi HG. 2007. Seasonal community structure and vertical distribution of medicinal seaweeds at Kkotji in Taean Peninsula, Korea. Algae 22, 209-219.

Lee WJ, Yoon HS and Boo SM. 1997. Marine algal community of Gyonggiman Islets on the West Sea of Korea. Algae 12, 139-144.

Lee YP and Kang SY. 2002. A Catalogue of the Seaweeds in Korea. Cheju National University Press, Cheju, Korea 662pp.

Littler MM and Littler DS. 1980. The evolution of thallus form and survival strategies in benthic marine macroalgae: field and laboratory tests of a functional form model. Am Nat 116, 25-44.

Littler MM and Littler DS. 1984. Relationships between macroalgal functional form groups and substrata stability in a subtropical rocky-intertidal system. J Exp Mar Biol Ecol 74, 13-34.

McNaughton SJ. 1967. Relationships among functional properties of
California Grassland. Nature 216, 168-169.

Murray SN and Littler MM. 1984. Analysis of seaweed communities in a disturbed rocky intertidal environment near Whites Point, Los Angeles, Calif., U.S.A. Hydrobiologia 116/117, 374-382.

Padilla DK and Allen BJ. 2000. Paradigm lost : reconsidering functional form and group hypotheses in marine ecology. J Exp Mar Biol Ecol 250, 207-221.

Park YS and Kim YH. 1990. Phytogeographical study on the summer marine algal distribution in western coast of Korea. Korean J Phycol 5, 39-50

Phillips JC, Kendrick GA and Lavery PS. 1997. A test of a functional group approach to detecting shifts in macroalgal communities along a disturbance gradient. Mar Ecol Prog Ser 153, 125-138.

Piazzi L, Pardi G, Balata D, Cecchi E and Cinelli F. 2002. Seasonal dynamics of a subtidal north-western Mediterranean macroalgal community in relation to depth and substrate inclination. Bot Mar $45,243-252$

Prathep A. 2005. Spatial and temporal variations in diversity and percentage cover of macroalgae at Sirinart marine national park, Phuket Province, Thailand. Sci Asia 31, 225-233.

Saito Y and Atobe S. 1970. Phytosociological study of intertidal marine algae I. Usujiri Benten-Jima, Hokkaido. Bull Fac Fish Hokkaido Univ 21, 37-69.

Schramm W. 1999. Factors influencing seaweed responses to eutrophication : some results from EU-project EUMAC. J Appl Phycol 11, 69-78.

Steneck RS and Dethier MN. 1994. A functional group approach to the structure of algal-dominated communities. Oikos 69, 476-498.

Terawaki T, Hasegawa H, Arai S and Ohno M. 2001. Management-free techniques for restoration of Eisenia and Ecklonia beds along the central Pacific coast of Japan. J Appl Phycol 13, 13-17.

Vásquez JA and Guerra N. 1996. The use of seaweeds as bioindicators of natural and anthropogenic contaminants in northern Chile. Hydrobiologia 326/327, 327-333.

Wan XQ, Park HH, Yoo HI and Choi HG. 2009. Temporal variations in seaweed biomass and coverage in Korean coasts: Ongdo, Chungnam. Fish Aqua Sci 12, 130-137.

Wells E, Wilkionson M, Wood P and Scanlan C. 2007. The use of macroalgal species richness and composition on intertidal rocky seashores in the assessment of ecological quality under the European water framework directive. Mar Pollut Bull 55, 151-161.

Weston DP. 1990. Quantitative examination of macrobenthic community changes along an organic enrichment gradient. Mar Ecol Prog Ser 61, 233-244.

Yoo HI, Lee JH, Lee KH, Beak SH, Heo YB, Noh HS and Choi HG. 2007. Summer marine algal floras and community structures in Taean Peninsula, Korea. J Korean Fish Soc 40, 210-219.

Yoon MY and Boo SM. 1991. Flora and zonation of marine plants at the littoral area of Sapsido island on the Yellow sea of Korea. Korean J Phycol 6, 145-156. 